\title{
LATIHAN PEREGANGAN PADA PENDERITA NYERI PUNGGUNG BAWAH
}

\author{
Fitra Puspita Sari, Husni, Hermansyah
Politeknik Kesehatan Kementerian Kesehatan Bengkulu, Jurusan Keperawatan, Jalan Indragiri Nomor 03 Padang Harapan Bengkulu Fitrapuspitasari097@Gmail.Com

\begin{abstract}
The incidence of low back pain is about $80 \%$ of the population have suffered from low back pain. Data of low back pain patients within 6 months (April to September 2016) as many as 72 visits in Poly Saraf RSUD Bengkulu City. The purpose of the study to determine the effect of stretching on the reduction of the scale of pain in low back pain patients in Poly Saraf RSUD Bengkulu City. The type of research is pre-experiment with one group pre-test post-test design. Respondents were lower back pain patients as many as 32 people taken with purposive sampling technique. Data collection was done by interview using numerical pain scale. The result showed that the average of pain scale before stretching was 4.81 with a standard deviation of 0.592 , the pain scale after stretching was 3.34 with a standard deviation of 0.701. Stretching exercises have a significant effect on decreasing the scale of low back pain $(p=0.000 \leq \alpha 5 \%)$. It is desirable for nurses to apply stretching exercises as an initial measure to lower the scale of low back pain.
\end{abstract}

Keywords: pain, exercise, stretching

\begin{abstract}
Abstrak: Insiden nyeri punggung bawah sekitar $80 \%$ dari populasi pernah menderita nyeri punggung bawah. Data pasien nyeri punggung bawah dalam kurun waktu 6 bulan (april hingga september 2016) sebanyak 72 kunjungan di Poli Saraf RSUD Kota Bengkulu. Tujuan dari penelitian untuk mengetahui pengaruh peregangan terhadap penurunan skala nyeri pada penderita nyeri punggung bawah di Poli Saraf RSUD Kota Bengkulu. Jenis penelitian adalah pra-eksperimen dengan desain one group pre-test posttest. Responden adalah penderita nyeri punggung bawah sebanyak 32 orang yang diambil dengan tekhnik pengambilan sampel purposive sampling. Pengumpulan data dilakukan dengan interview menggunakan skala nyeri numerik. Hasil analisa menunjukkan rata rata skala nyeri sebelum dilakukan peregangan adalah 4,81 dengan standar deviasi 0,592, skala nyeri sesudah dilakukan peregangan adalah 3,34 dengan standar deviasi 0,701. Latihan peregangan mempunyai pengaruh yang signifikan terhadap penurunan skala nyeri punggung bawah $(p=0,000 \leq \alpha 5 \%)$. Diharapkan kepada perawat untuk menerapkan latihan peregangan sebagai tindakan awal untuk menurunkan skala nyeri punggung bawah.
\end{abstract}

Kata Kunci : nyeri, latihan, peregangan

Punggung dan tulang belakang hampir selalu terlibat dalam aktivitas manusia. Dalam kaitanya dengan problem ganguan fisik yang berhubungan dengan alat gerak tubuh, gangguan tulang belakang adalah salah satu dari sekian banyak gangguan akibat kerja, baik itu dilihat dari susunannya, fungsinya, maupun proses patologinya. Daerah lumbal terdiri atas L1 sampai L5 dan L5 - S1 yang paling besar menerima beban atau berat tubuh sehingga daerah lumbal menerima gaya dan stres mekanikal paling besar sepanjang vertebra (Belliner, 2008). Salah satu gangguan fisik yang sering dialami adalah nyeri punggung bawah atau Low Back Pain. Low Back Pain (LBP) atau yang sering disebut dengan nyeri punggung bawah (NPB) merupakan keluhan yang sering dijumpai. nyeri punggung bawah untuk selanjutnya 
adalah nyeri yang dirasakan di daerah punggung bawah, dapat merupakan nyeri lokal maupun nyeri radikular atau keduanya (Mahadewa \& Maliawan,2009). Nyeri ini terasa diantara sudut iga terbawah dan lipat bokong bawah yaitu di daerah lumbal atau lumbal-sakral dan sering disertai dengan penjalaran nyeri ke arah tungkai dan kaki.

$$
\text { Dari data epidemiologi }
$$

menunjukkan nyeri punggung bawah masuk pada urutan yang ke 19 dengan presentase $27 \%$, dan prevalensi dirasakan seumur hidup sebanyak $60 \%$ (Demoulin et al, 2012). Menurut World Health Organization (WHO), 2-5\% dari karyawan di negara industri tiap tahun mengalami nyeri punggung bawah, dan $15 \%$ dari absenteisme di industri baja serta industri perdagangan disebabkan karena nyeri punggung bawah (Muheri 2010; Sakinah et al, 2012).

Di Amerika Serikat lebih dari $80 \%$ penduduk pernah mengeluh Nyeri Punggung Bawah dan di negara kita sendiri diperkirakan jumlahnya lebih banyak lagi. Nyeri punggung bawah merupakan 1 dari 10 penyakit terbanyak di Amerika Serikat dengan angka prevalensi berkisar antara 7,6-37\%. Puncak insidensi nyeri punggung bawah adalah pada usia 45- 60 tahun . Pada penderita dewasa tua, nyeri punggung bawah dapat mengganggu aktivitas sehari-hari pada $40 \%$ penderita, dan gangguan tidur pada $20 \%$ penderita. Sebagian besar $(75 \%)$ penderita akan mencari pertolongan medis, dan $25 \%$ diantaranya perlu dirawat inap untuk evaluasi lebih lanjut (Dachlan, 2009).

Etiologi nyeri punggung bawah menurut John W.Engstrom dalam Johannes (2010) dapat disebabkan oleh beberapa faktor yaitu kongenital/ perkembangan, trauma minor (tegang atau keseleo, tertarik), fraktur, hernia diskus intervertebral, degeneratif, artritis, metastase neoplasma/ tumor,infeksi/inflamasi, metabolik, dan lainnya yaitu psikiatri, diseksi arteri vertebral, postural. Postural dalam hal ini adalah contohnya sikap duduk, dimana sikap duduk yang tidak baik seperti membungkuk ke depan, tidak tegap, kepala menunduk, dada kempis, dinding perut menonjol dan cekung kedepan pada kurvatura lumbal yang berlebihan (hiperlordotic). Semua posisi diatas akan menyebabkan pusat gaya berat jatuh kedepan. Sebagai kompensasinya, punggung tertarik kebelakang,-menyebabkan hiperlordotic pada daerah lumbal. Jika keadaan ini berlangsung lama maka akan menyebabkan tulang punggung beserta jaringan tendon dan otot dipaksa untuk menjaga tubuh bagian atas secara berlebihan, sehingga terjadi kelelahan pada otot punggung, terutama otot -otot daerah lumbal (Rahardian, 2013).

Sedikit sekali penderita yang mengerti bahwa bila kita memiliki otot yang kuat dan sikap tubuh yang tegap akan dapat mencegah nyeri punggung. Hal tersebut kemudian menimbulkan anggapan (yang salah) bahwa keadaan NPB sebagai hal yang wajar sejalan dengan bertambahnya usia dan atau akibat kerja terlalu berat, salah mengangkat baban berat, atau ranjang yang terlalu empuk. Anggapan yang salah ini dapat memperparah kondisi nyeri punggung bawah dimana penderita tersebut tidak melakukan pemeriksaan dan pengobatan yang sesuai. Hal ini dapat menghasilkan dampak yang buruk pada penderita nyeri punggung bawah itu sendiri,seperti nyeri yang mengganggu, bertambah parahnya penyakit nyeri punggung bawah, berkurangnya kemandirian dalam aktivitas sehari-hari, hingga kinerja dari penderita menurun.

Faktor risiko terjadinya nyeri punggung bawah antara lain usia, indeks massa tubuh, kehamilan dan faktor psikologi. Seorang yang berusia lanjut akan mengalami nyeri punggung bawah karena penurunan fungsi-fungsi tubuhnya 
terutama tulang, sehingga tidak lagi elastis seperti diwaktu muda. Sedangkan postur merupakan faktor pendukung nyeri punggung bawah. Kesalahan postur seperti bahu melengkung ke depan, perut menonjol ke depan dan lordosis lumbal berlebihan dapat menyebabkan spasme otot (ketegangan otot). Hal ini merupakan penyebab terbanyak dari nyeri punggung bawah. nyeri punggung bawah juga terjadi karena berbagai faktor, diantaranya faktor pekerjaan yang melibatkan aktivitas yang berlebihan seperti mengangkat benda yang berat (Tomita, 2010).

Menurut Muhith (2014)

mengatakan bahwa orang yang menyempatkan melakukan olah tubuh minimal 30 menit setiap hari dapat memberikan keuntungan yang berlipat dan itu akan bertahan walaupun usia bertambah. Latihan untuk mengurangi gangguan pada vertebra lumbal dapat diberikan William Fleksi, dimana dalam latihan ini pada vertebra lumbal baik otot maupun curva vertebra di koreksi dan dilakukan stretching untuk menurunkan ketegangan otot yang ada, meningkatkan sirkulasi darah yang berkurang dengan proses adanya peregangan. Bentuk latihan yang digunakan dalam penelitian ini dipilih dengan alasan lebih murah, mudah dilakukan, praktis dan dapat dijadikan sebagai home edukasi sehingga memungkinkan penderita dapat melakukan tindakan preventif jika dilakukan setelah bekerja, mengurangi spasme dan rasa pegal yang ditimbulkan sehabis duduk lama.

Dari hasil studi pendahuluan yang dilakukan peneliti di RSUD Kota Bengkulu pasien mengalami keluhan nyeri punggung bawah adalah kunjungan terbanyak setiap bulannya. Data di Poli saraf RSUD Kota Bengkulu pada tahun 2015 sebanyak 79 orang dari total 668 kunjungan dengan lebih dari 36 diganosa penyakit. Data pasien dengan nyeri punggung bawah dalam kurun waktu 6 bulan (april hingga september 2016) dengan jumlah kunjungan 72 dari seluruh kunjungan ke Poli Saraf RSUD Kota Bengkulu. Hal ini menunjukkan bahwa terjadinya peningkatan jumlah kunjungan pasien nyeri punggung bawah. RSUD Kota Bengkulu merupakan rumah sakit yang baru berdiri, sehingga belum maksimalnya penggunaan fasilitas yang tersedia, seperti belum dilakukan fisioterapi pada pasien dengan Nyeri Punggung Bawah baik Microwafe diatermi ataupun infra merah. Dari survey penelitian data pasien NPB di Poli Saraf RSUD Kota Bengkulu tersebut hanya diberikan terapi analgetik yang sama baik sewaktu kunjungan pertama hingga kunjungan berikutnya dan jenis analgetik yang diberikan merupakan analgetik yang tidak dapat dikonsumsi dalam jangka panjang dan banyak efek samping yang ditimbulkan oleh analgetik tersebut, seperti mengalami sakit perut seperti mulas, mengantuk, sakit kepala ringan, sindrom neuropati, dan efek samping lain. Dari latar belakang tersebut diatas, maka peneliti tertarik untuk melakukan penelitian pengaruh peregangan terhadap penurunan skala nyeri pada penderita nyeri punggung bawah di poli saraf RSUD Kota Bengkulu.

\section{BAHAN DAN CARA KERJA}

Penelitian ini adalah pre eksperimen dengan desain yaitu; "one group pre-test post-test" yaitu rancangan penelitian ini tidak ada kelompok pembanding (control) tetapi paling tidak, sudah dilakukan observasi pertama (pretest) yang memungkinkan penelitian dapat menguji perubahan yang terjadi setelah adanya eksperimen. Populasi pada penelitian ini adalah seluruh klien yang menderita nyeri punggung bawah di Poli Saraf RSUD Kota Bengkulu yaitu 72 orang. Data dianalisa secara univariat dan bivariat. 


\section{HASIL}

\section{Analisa Univariat}

Analisa univariat pada penelitian ini untuk melihat nilai mean, nilai minimal maksimal, standar deviasi dan 95\% CI mean karakteristik responden dan pengukuran skala nyeri pada pasien nyeri

Tabel 1 menunjukkan bahwa ratarata umur responden adalah 44,16 tahun dengan standar deviasi 7,085 tahun. Dari hasil estimasi interval disimpulkan bahwa 95\% diyakini rata-rata umur responden antara 41,81-46,50 tahun.

Grafik 1 Distribusi Responden Bedasarkan Jenis Kelamin di Poli Saraf RSUD Kota Bengkulu

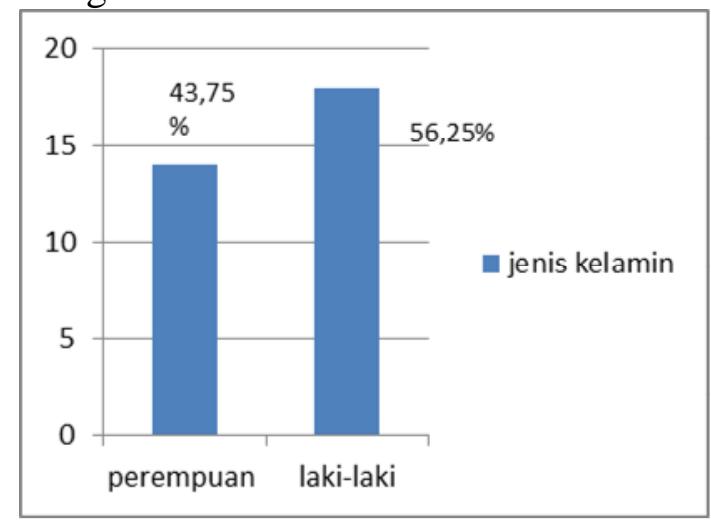

Grafik 1 menunjukkan bahwa lebih dari sebagian responden $(56,25 \%)$ berjenis kelamin laki-laki.

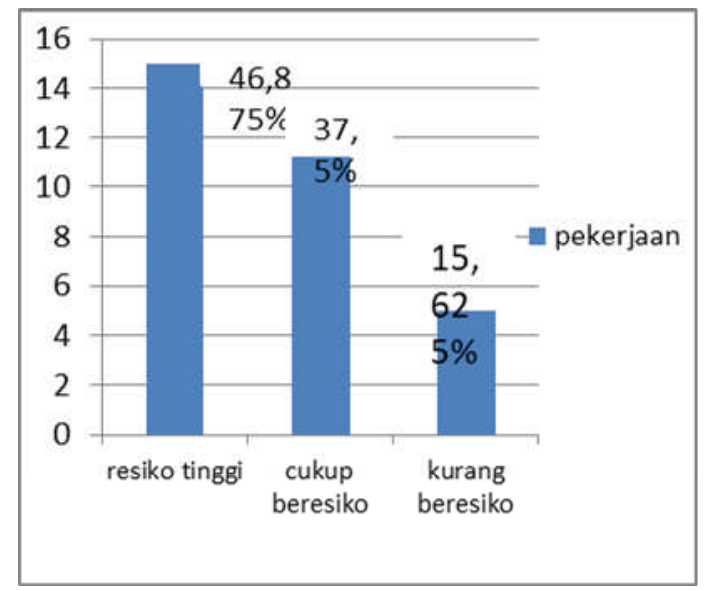

Grafik 2 menunjukkan bahwa diatas didapatkan bahwa sebagian $(46,875 \%)$ responden memiliki pekerjaan yang punggung bawah sebelum dan sesudah diberikan latihan stretching fleksi william.

Tabel 1. Distribusi Responden Bedasarkan Umur di Poli Saraf RSUD Kota Bengkulu

\begin{tabular}{lllllll}
\hline $\begin{array}{l}\text { Jenis } \\
\text { kelomp } \\
\text { ok }\end{array}$ & $\mathrm{N}$ & $\begin{array}{l}\mathrm{Me} \\
\text { an }\end{array}$ & $\begin{array}{l}\mathrm{Me} \\
\text { dia } \\
\mathrm{n}\end{array}$ & $\mathrm{SD}$ & $\begin{array}{l}\text { Min- } \\
\text { mak }\end{array}$ & $95 \% \mathrm{CI}$ \\
\hline Interven & 3 & 44, & 45, & 7,0 & $30-$ & $41,81-$ \\
si & 2 & 16 & 50 & 85 & 57 & 46,50 \\
\hline
\end{tabular}

beresiko tinggi (petani, buruh bangunan, buruh pabrik, kuli angkut) menjadi penyebab nyeri punggung bawah.

Table 2 Distribusi Responden Berdasarkan Skala Nyeri Pre dan Post Latihan Stretching Fleksi William Di RSUD Kota Bengkulu tahun 2017

\begin{tabular}{lllllll}
\hline $\begin{array}{l}\text { Variab } \\
\text { el }\end{array}$ & $\mathrm{N}$ & $\begin{array}{l}\text { Mea } \\
\mathrm{n}\end{array}$ & $\begin{array}{l}\text { Medi } \\
\text { an }\end{array}$ & SD & $\begin{array}{l}\text { Min- } \\
\text { maks }\end{array}$ & $\begin{array}{l}95 \% \text { CI } \\
\text { for } \\
\text { mean }\end{array}$ \\
\hline Pre & 3 & 4,81 & 5,00 & 0,5 & $4-6$ & $4,60-$ \\
test & 2 & & & 92 & & 5,03 \\
Post & 3 & 3,34 & 3,00 & 0,7 & $2-5$ & $3.09-$ \\
test & 2 & & & 01 & & 3,60 \\
\hline
\end{tabular}

Tabel 2 menunjukkan rata-rata skala nyeri sebelum dilakukan latihan adalah 4,81 dengan Standar Deviasi 0,592. Dari hasil estimasi interval disimpulkan bahwa $95 \%$ diyakini rata-rata skala nyeri responden sebelum latihan berada pada nyeri sedang. Sedangkan rata-rata skala nyeri setelah dilakukan latihan adalah 3,34 dengan standar deviasi 0,0701. Dari hasil estimasi interval disimpulkan bahwa $95 \%$ diyakini rata-rata skala nyeri responden berada pada skala nyeri ringan.

Table 3 Distribusi Responden Berdasarkan Penurunan Skala Nyeri Post Latihan Stretching Fleksi William Di RSUD Kota Bengkulu tahun 2017

\begin{tabular}{lllll}
\hline Kriteria & Frekuensi & $\%$ & \\
\hline & Pre Test & $\begin{array}{l}\text { Post } \\
\text { Test }\end{array}$ & $\begin{array}{l}\text { Pre } \\
\text { Test }\end{array}$ & $\begin{array}{l}\text { Post } \\
\text { Test }\end{array}$ \\
\hline Berat & 0 & 0 & $0 \%$ & $0 \%$ \\
Sedang & 32 & 12 & $100 \%$ & $37,5 \%$ \\
Ringan & 0 & 20 & $0 \%$ & $62,5 \%$ \\
\hline
\end{tabular}

Tabel 3 menunjukkan bahwa lebih dari sebagian $(62,5 \%)$ responden mengalami penurunan skala nyeri setelah 
dilakukan latihan peregangan dari nyeri sedang ke nyeri ringan.

\section{Analisa Bivariat}

Analisa bivariat dilakukan untuk mengetahui adanya penurunan skala nyeri sebelum dan setelah dilakukan latihan stretching fleksi william. Sebelum dilakukan analisa terlebih dahulu di uji kenormalan data untuk menentukan jenis uji statistik yang akan dilakukan. Uji kenormalan data menggunakan SPSS, didapatkan bahwa data berdistribusi Tidak Normal. Sehingga dilakukan analisis menggunakan uji wilcoxon dan didapatkan hasil sebagai berikut :

Tabel 4 Pengaruh Latihan Peregangan Terhadap Tingkat Nyeri Punggung Bawah Pada Pasien Di Poli Saraf RSUD Kota Bengkulu

\begin{tabular}{lcccc}
\hline Intensitas Nyeri & $\mathrm{N}$ & $\begin{array}{l}\text { Mean } \\
\text { Rank }\end{array}$ & $\begin{array}{l}\text { Sum of } \\
\text { Ranks }\end{array}$ & $p$ value \\
\hline $\begin{array}{l}\text { Sebelum- } \\
\text { Sesudah } \\
\text { intervensi }\end{array}$ & 32 & 16,50 & 528,0 & 0,000 \\
\hline
\end{tabular}

Hasil uji statistik menunjukkan bahwa ada pengaruh latihan peregangan terhadap penurunan skala nyeri pada pasien dengan nyeri punggung bawah $(\mathrm{P}=0,000)$.

\section{PEMBAHASAN}

Pembahasan akan diuraikan tentang makna hasil penelitian serta membandingkannya dengan teori dan penelitian terkait, serta mendiskusikan hasil penelitian yang telah diuraikan pada bab hasil. Sesuai dengan tujuan khusus penelitian ini, maka pembahasan hasil penelitian dilakukan untuk mengetahui pengaruh latihan peregangan terhadap penurunan intensitas nyeri pada pasien nyeri punggung bawah.

\section{Gambaran Karakteristik Responden di Poli Saraf RSUD Kota Bengkulu}

Berdasarkan hasil penelitian didapatkan rata-rata usia penderita nyeri punggung bawah 44,16 tahun. Hasil penelitian ini sejalan dengan hasil penelitian Kurniawan (2004) rata-rata umur penderita nyeri punggung bawah 44,5. Lebih dari sebagian $(56,24 \%)$ berjenis kelamin laki-laki. Hal ini sejalan dengan penelitian yang dilakukan Susanti (2008) karakteristik responden menurut jenis kelamin menunjukkan bahwa lebih dari sebagian penderita nyeri punggung bawah (54\%) berjenis kelamin laki-laki.

Hampir sebagian $(46,875 \%)$ penderita nyeri punggung bawah memiliki pekerjaan yang beresiko tinggi (buruh bangunan, petani, buruh pabrik, kuli angkut) menyebabkan nyeri punggung bawah. Sejalan dengan penelitian Nurlis (2010) hampir sebagian $(43 \%)$ penderita nyeri punggung bawah bekerja sebagai petani, buruh bangunan, buruh pabrik dan pedagang. Sejalan dengan penelitian Tomita (2010) Faktor risiko yang paling sering dilaporkan untuk nyeri pinggang adalah beban kerja fisik yang berat seperti mengangkat, posisi tubuh membungkuk, dan getaran seluruh tubuh. Gaya hidup juga dianggap sebagai faktor risiko dari nyeri pinggang. Merokok, kurangnya latihan fisik, dan jam tidur yang pendek meningkatkan risiko nyeri pinggang. Pekerja pengolah pangan diketahui sebagai populasi yang berisiko tinggi mengalami nyeri pinggang karena mereka bekerja dalam posisi membungkuk, mengangkat bahan yang berat, di lantai yang basah, dan suhu yang panas.

\section{Gambaran Intensitas Nyeri Sebelum Intervensi latihan stretching fleksi william Pada pasien Nyeri punggung bawah di RSUD Kota Bengkulu.}

Hasil penelitian menunjukkan rata rata intensitas nyeri punggung bawah sebelum dilaksanakan latihan stretching fleksi william adalah 4,81. Hasil penelitian ini memberikan gambaran bahwa rata-rata intensitas nyeri pasien nyeri punggung bawah sebelum dilakukan intervensi latihan stretching fleksi william dalam kategori nyeri sedang (4-6). Sejalan dengan penelitian Anggraini (2015) 
menunjukkan bahwa rata-rata skala nyeri penderita nyeri punggung bawah sebelum diberi terapi adalah kategori nyeri sedang $(5,36)$.

Nyeri punggung bawah atau LBP adalah nyeri yang terbatas pada regio lumbal, tetapi gejalanya lebih merata dan tidak hanya terbatas pada satu radiks saraf, namun secara luas berasal dari diskus intervertebralis lumbal. Keluhan Nyeri punggung bawah sangat beragam, tergantung dari patofisiologi, perubahan biokimia atau biomekanik dalam discus intervertebralis. Bahkan pola patofisiologi yang serupa pun dapat menyebabkan sindroma yang berbeda dari pasien. Pada umumnya sindroma lumbal adalah nyeri. Sindroma nyeri muskulo skeletal yang menyebabkan Nyeri punggung bawah termasuk sindrom nyeri miofasial dan fibromyalgia (Dachlan, 2009).

\section{Gambaran Intensitas Nyeri Sesudah Intervensi latihan stretching fleksi william Pada pasien Nyeri punggung bawah di RSUD Kota Bengkulu.}

Hasil analisis menunjukkan rata rata intensitas nyeri punggung bawah sesudah dilaksanakan latihan stretching fleksi william adalah 3,34. Hasil penelitian ini memberikan gambaran bahwa rata-rata intensitas nyeri pasien nyeri punggung bawah sesudah dilakukan intervensi latihan stretching fleksi william masuk dalam kategori nyeri ringan (1-3).

Sejalan dengan penelitian Anggraini (2015) menunjukkan bahwa rata-rata skala nyeri pada penderi nyeri punggung bawah setelah dilakukan intervensi masuk dalam kategori nyeri ringan $(3,04)$.

\section{Pengaruh latihan stretching fleksi william terhadap Penurunan Nyeri punggung bawah pada pasien dengan nyeri punggung bawah di RSUD Kota Bengkulu}

Hasil penelitian menunjukkan bahwa ada pengaruh latihan peregangan terhadap penurunan skala nyeri punggung bawah pada pasien dengan nyeri punggung bawah $(\mathrm{P}=0,000)$. Hasil penelitian sejalan dengan penelitian Muhith dkk (2014) menyimpulkan bahwa ada pengaruh pemberian terapi william flexion exercise terhadap nyeri punggung bawah pada lansia $(\mathrm{P}=0.03)$.

Hasil penelitian sejalan dengan Penelitian Anggaraeni (2015), hasil Penelitian menunjukkan bahwa ada manfaat peregangan otot terhadap keluhan nyeri punggung bawah pada pekerja bagian knitting gantung PT. Royal Korindah Purbalingga $(\mathrm{p}<0,05)$. Hasil penelitian juga sejalan dengan penelitian Kurniawan (2004), bahwa ada pengaruh Back Exercise dalam peningkatan lingkup gerak sendi $(\mathrm{P}<0.05)$.

Hasil penelitian sejalan dengan pendapat Dachlan (2009) menunjukkan pengurangan keluhan nyeri pada kelompok perlakuan dengan metode Mc Kenzie dan kelompok perlakuan dengan metode William Flexion dikatakan tidak berbeda $(\mathrm{P}=0,19)$.

Latihan kelenturan otot-otot punggung bawah metode fleksi william meningkatkan kekuatan otot pinggang. Nyeri yang diakibatkan karena melemahnya otot pinggang, dapat berkurang dengan latihan peregangan. Hal ini ada kaitanya dengan kerja otot yang menjalankan fungsinya dengan berpasangan. Otot-otot menjalankan fungsinya dengan berpasangan yaitu pada saat kumpulan otot agonist dalam keadaan berkontraksi maka otot antagonist yang berlawanan dalam keadaan rileks. Latihan merupakan program rehabilitasi guna meningkatkan kekuatan otot punggung dan abdomen, seperti halnya latihan stretching untuk meningkatkan fleksibilitas, juga mengurangi berat badan. Hal yang sama menurut Kisner (1990) back exercise yang diberikan secara baik dan benar mempunyai efek mengurangi nyeri, menambah lin gkup gerak sendi, memperbaiki elastisitas jaringan dan memperlancar peredaran darah. 


\section{KESIMPULAN}

Berdasarkan hasil penelitian dan pembahasan ada pengaruh latihan peregangan terhadap penurunan skala nyeri pada pasien dengan nyeri punggung bawah di Poli Saraf RSUD Kota Bengkulu.

Bagi kepala ruangan selaku penanggung jawab di Poli Saraf RSUD Kota Bengkulu diharapkan mampu menerapkan latihan peregangan fleksi william terhadap pasien nyeri punggung bawah di rumah sakit tersebut. Sebaiknya kepala ruangan melakukan penyuluhan atau pelatihan tentang Stretching William flexion exercise kepada perawat di Poli saraf.

Bagi institusi pendidikan Memasukkan materi terapi peregangan William Flexion Exercise kedalam bahan pembelajaran mata kuliah Keperawatan Medikal Bedah sebagai salah satu contoh terapi komplementer. Agar dapat

\section{DAFTAR RUJUKAN}

Belliner. 2008. A biomechanical analysis of the clinical stability of the lumbar and lumbrosacral spine: Phildelphia.

Dachlan, Leo Muhammad. 2009. Pengaruh Back Exercise Pada Nyeri Punggung Bawah.

Johanes, 2010. Hubungan Antara Postur Tubuh dengan Terjadinya Nyeri Punggung Bawah pada Pasien Poliklinik Neurologi di RSUP H. Adam Malik Medan 2010, USU: Fakultas Kedokteran Universitas Sumatera Utara.

Mahadewa, T. G. B., \& Maliawan, S. (2009). Diagnosis dan tatalaksana kegawat daruratan tulang belakang. Jakarta: Sagung seto.

Muhith, abdul.Angga Novida. 2014. Pengaruh Terapi William Flexion Exercise Terhadap meningkatkan kemampuan mahasiswa dalam melakukan manajemen nyeri salah satunya dengan metode latihan peregangan fleksi william.

Peneliti lain diharapkan dapat mengkaji faktor lain (penggunaan tehnik distraksi, imajinasi, hipnotis, dan lain-lain) yang mempengaruhi penurunan nyeri pasien nyeri punggung bawah. Penelitiannya dapat dilakukan dengan memperbanyak sampel yang diteliti sesuai dengan rumus perhitungan sampel dan menggunakan desain penelitian kuasi eksperimen yang menggunakan kelompok pembanding (control), melakukan pengontrolan terhadap variabel perancu seperti umur, jenis kelamin, aktivitas, posisi tubuh dan lain-lain, serta cara pengambilan sampel dilakukan secara random ,sehingga didapatkan hasil yang lebih maksimal.

Nyeri Punggung Bawah Pada Lansia Di Panti Werdha Mojopahit Mojokerto.

Sakinah, et.al. 2012. Faktor Yang Berhubungan Dengan Keluhan Nyeri Punggung Bawah Pada Pekerj Batu Bata Di Kelurahan Lawawoi Kabupaten Sidrap. Jurnal Bagian Kesehatan dan Keselamatan Kerja FKM Universitas Hasanuddin Makassar.

Tomita S, Arphorn S, Muto T, et al. 2010. Prevalence and risk factors of low back pain among thai and myanmar migrant seafood processing factory workers in Samut Sakorn Province, Thailand. Industrial Health 2010; 48: 283-291 